\title{
Do Federal Reserve policy surprises affect the risk perception in the emerging markets?
}

\section{Onur Ince \& Umit Ozlale}

To cite this article: Onur Ince \& Umit Ozlale (2006) Do Federal Reserve policy surprises affect the risk perception in the emerging markets?, Applied Financial Economics Letters, 2:5, 329-332, DOI: 10.1080/17446540600583547

To link to this article: http://dx.doi.org/10.1080/17446540600583547

曲 Published online: 02 Feb 2007.

6 Submit your article to this journal $\pi$

Џ Article views: 21

Q View related articles $\smile$ 


\title{
Do Federal Reserve policy surprises affect the risk perception in the emerging markets?
}

\author{
Onur Ince and Umit Ozlale* \\ Department of Economics, Bilkent University, Bilkent 06800, \\ Ankara, Turkey
}

\begin{abstract}
Employing an event study approach, the present authors analyse whether the Federal Reserve's policy surprises affect the risk perceptions in the emerging markets. Only weak evidence is found when the Federal Reserve follows a more expansionary policy than expected. For all other cases, the policy surprises of the Federal Reserve are ineffective.
\end{abstract}

\section{Introduction}

It has been well documented that the financial markets in the USA react strongly to the policy changes of the Federal Reserve (FED). After the FED explicitly stated that it would continue to tighten its policy also in the second half 2005, the interest on this issue gained further importance. In this context, Kuttner (2001) and Bernanke and Kuttner (2004) find that the reactions of the financial markets to a policy change are much stronger when the FED's policy change is unanticipated, i.e. when there is a surprise component in the federal funds rate.

This study extends the effects of these policy surprises to emerging market economies, which has not been investigated before. More specifically, it focuses on the changes in the perceived risk for these economies when there is a policy surprise by the FED. As the financial markets become more interconnected, these policy surprises can be critical for the emerging markets. While a more aggressive policy change than the expected can increase the risk premium that is demanded by the foreign investors to stay in these emerging markets and thus increases the risk perceptions, an expansionary policy surprise can generate capital flows to these markets, which decreases the country-specific risk component.

As the next section elaborates, it analyzes the above-mentioned question for 12 emerging markets within an event-study framework by concentrating on the Emerging Markets Bond Index (EMBI) spread, prepared by the J. P. Morgan. Next, the rank test of Cragg and Donald (1997) is performed to identify whether there are other factors in the specified event window, which affect the EMBI spread other than the surprise component of the federal funds rates. Finally, it is investigated whether the FED's policy surprises also have effects on the exchange rates for the examined emerging markets.

\section{The Data and the Methodology}

Based on the data availability, 12 emerging markets are employed for the sample period between 31 December 1997 and 20 July 2004. These countries are Brazil, Bulgaria, Egypt, Mexico, Nigeria, Panama, Peru, Poland, Russia, South Africa, Turkey and Venezuela. The FED's policy surprise

*Corresponding author. E-mail: ozlale@bilkent.edu.tr 
Table 1. Expected results on FED surprises

\begin{tabular}{lllll}
\hline Policy & Expected & Actual & Result & Expected $\Delta$ in EMBI \\
\hline Loose policy & f.f.r. $\downarrow$ & f.f.r. $\downarrow$ & Looser than expected & EMBI decreases \\
Tight policy & f.f.r. $\downarrow$ & f.f.r. $\downarrow$ & Less loose than expected & EMBI increases \\
& f.f.r. $\uparrow$ & f.f.r. $\uparrow$ & Tighter than expected & EMBI increases \\
& f.f.r. $\uparrow$ & f.f.r. $\uparrow$ & Less tight than expected & EMBI decreases \\
\hline
\end{tabular}

Table 2. Results when FED follows tighter policy than the expected

\begin{tabular}{|c|c|c|c|c|c|}
\hline Dates & Actual $\Delta$ & $\begin{array}{l}\text { Policy } \\
\text { surprise }\end{array}$ & Expected $\Delta$ & $\begin{array}{l}\text { Expected } \Delta \\
\text { in EMBI }\end{array}$ & $\begin{array}{l}\text { Unexpected } \Delta \\
\text { in EMBI }\end{array}$ \\
\hline 24.08.1999 & 0.25 & 0.02 & 0.23 & Egypt, Poland, S. Africa & Brazil, Nigeria, Peru \\
\hline 16.11.1999 & 0.25 & 0.09 & 0.16 & Brazil, Egypt & $\begin{array}{l}\text { Venezuela, Nigeria, Panama, Russia, } \\
\text { Turkey, S. Africa }\end{array}$ \\
\hline 16.05.2000 & 0.50 & 0.05 & 0.45 & $\begin{array}{l}\text { Brazil, Peru, Venezuela, } \\
\quad \text { Poland, Russia, Turkey }\end{array}$ & Egypt \\
\hline
\end{tabular}

data were borrowed from Bernanke and Kuttner (2004) and Gurkaynak et al. (2005).

As mentioned above, the country-specific EMBI spreads are used to analyse the effects of the FED's policy surprises on these countries. Working with the EMBI spreads have several advantages. First, since it is constructed as excess promised returns over the US treasuries, it can be conveniently used as a measure of risk for the emerging markets. Second, the liquidity and the maturity differences among different emerging markets are controlled for. Finally, and importantly, as Calvo (2002) argues, it truly reflects the 'risk appetite' of the foreign investors to invest in the emerging financial markets. In that sense, the EMBI spread better reflects the changes in the external factors, such as a policy surprise of the FED. Since an increase in the spread indicates a hike in the risk component for the corresponding emerging market, a tight policy surprise is expected to increase the spread while a loose surprise is expected to decrease the spread. In fact, Table 1 displays the four possible policy surprise cases and the expected change in the EMBI spread.

An event-study approach is followed for two reasons. First, as illustrated in MacKinlay (1997), such a methodology does not require the imposition of a structural model. This non-parametric characteristic of the methodology constitutes an advantage for a study, where macroeconomic dynamics and structures change significantly within and between the countries. Second, very rare policy changes can be observed but there exists a dense date. As discussed in Fatum and Hutchison (2003), time series techniques cannot capture the relationship adequately, when the variable of interest (federal funds rate in our case) has changed only a limited number of times.

\section{Results}

Table 1 shows the four possible cases where a policy surprise can be observed. The event are specified as the change in the federal funds rate by the FED. After the events were classified with respect to those four cases, the event study analysis was performed. For robustness purposes, both 5-day and 10-day event windows are used. While the former is used to express the short-term effect of the policy surprise, the latter is expected to indicate the long-term response of the EMBI spread to that policy surprise. In Tables 2-4, the change in the EMBI spreads are reported, only when there is a statistically significant change with respect to both event windows.

As Table 2 shows, there are three events in the sample period, where the FED follows a tighter policy than expected. It can be seen that only on 16.05.2000, the EMBI spread for half of the countries in the sample changes significantly in the expected direction. For the other two cases, the EMBI spread is either insensitive or changes in the unexpected direction.

We obtain similar results for the cases where the FED increases the federal funds rate less than the expected. Actually, for the latest two events in this group, there are more countries for which the EMBI spread moves in the unexpected direction. Thus, one can conclude that, when the FED follows a tight policy, irrespective of the sign of the 
Table 3. Results when the FED follows less tight policy than the expected

\begin{tabular}{|c|c|c|c|c|c|}
\hline Dates & Actual $\Delta$ & $\begin{array}{l}\text { Policy } \\
\text { surprise }\end{array}$ & Expected $\Delta$ & $\begin{array}{l}\text { Expected } \Delta \\
\text { in EMBI }\end{array}$ & $\begin{array}{l}\text { Unexpected } \Delta \\
\text { in EMBI }\end{array}$ \\
\hline 30.06.1999 & 0.25 & -0.04 & 0.29 & Venezuela, Mexico, Poland, Turkey & Brazil, Russia, S. Africa \\
\hline 02.02.2000 & 0.25 & -0.05 & 0.30 & Brazil, Nigeria, Peru, Turkey & Panama, Russia \\
\hline 21.03.2000 & 0.25 & -0.03 & 0.28 & Turkey & $\begin{array}{l}\text { Egypt, Mexico, Peru, } \\
\text { Nigeria, Poland, Venezuela }\end{array}$ \\
\hline 30.06 .2004 & 0.25 & -1.00 & 1.25 & Bulgaria, Nigeria, Venezuela & Poland, Turkey, S. Africa \\
\hline
\end{tabular}

Table 4. Results when the FED follows more expansionary policy than the expected

\begin{tabular}{llllll}
\hline Dates & Actual $\Delta$ & $\begin{array}{l}\text { Policy } \\
\text { surprise }\end{array}$ & Expected $\Delta$ & $\begin{array}{l}\text { Expected } \Delta \\
\text { in EMBI }\end{array}$ & $\begin{array}{l}\text { Unexpected } \Delta \\
\text { in EMBI }\end{array}$ \\
\hline 15.10 .1998 & -0.25 & -0.26 & 0.01 & ALL & NONE \\
17.11 .1998 & -0.25 & -0.06 & -0.19 & ALL except Nigeria, Egypt, Russia & NONE \\
03.01 .2001 & -0.50 & -0.38 & -0.12 & ALL except Nigeria & NONE \\
18.04 .2001 & -0.50 & -0.43 & -0.07 & Panama, Russia & Brazil, Bulgaria, Venezuela, \\
& & -0.08 & -0.42 & ALL except Bulgaria & NONE Poland, S. Africa \\
15.05 .2001 & -0.50 & -0.32 & -0.18 & NONE & ALL except Panama \\
17.09 .2001 & -0.50 & -0.07 & -0.43 & NONE & Brazil, Bulgaria, Egypt, Peru, \\
02.10 .2001 & -0.50 & & & Mexico, Poland, S. Africa \\
06.11 .2001 & -0.50 & -0.10 & -0.40 & ALL except Brazil, Egypt Mexico & Brazil \\
06.11 .2002 & -0.50 & -0.19 & -0.31 & Mexico, Poland & NONE
\end{tabular}

Table 5. Results when the FED follows less expansionary policy than the expected

\begin{tabular}{|c|c|c|c|c|c|}
\hline Dates & Actual $\Delta$ & $\begin{array}{l}\text { Policy } \\
\text { surprise }\end{array}$ & Expected $\Delta$ & $\begin{array}{l}\text { Expected } \Delta \\
\text { in EMBI }\end{array}$ & $\begin{array}{l}\text { Unexpected } \Delta \\
\text { in EMBI }\end{array}$ \\
\hline 31.01 .2001 & -0.50 & 0.01 & -0.51 & Nigeria, Panama & Peru \\
\hline 20.03.2001 & -0.50 & 0.06 & -0.56 & $\begin{array}{l}\text { Brazil, Bulgaria, Egypt, } \\
\text { Nigeria, Turkey }\end{array}$ & Russia \\
\hline 27.06.2001 & -0.25 & 0.05 & -0.30 & Brazil, Venezuela, Egypt & Poland, Russia \\
\hline 21.08.2001 & -0.25 & 0.02 & -0.27 & Mexico, Panama, Russia & $\begin{array}{l}\text { Brazil, Venezuela, Poland, } \\
\text { Turkey, S. Africa }\end{array}$ \\
\hline 25.06.2003 & -0.25 & 0.15 & -0.40 & $\begin{array}{l}\text { Brazil, Bulgaria, Venezuela, } \\
\text { Poland, S. Africa }\end{array}$ & Peru \\
\hline
\end{tabular}

surprise component, the EMBI spread does not seem to react much to such a policy change.

Next, the case, where the FED decreases the federal funds rates more than the expected is examine. There are nine events to observe, which are reported in Table 4.

For 5 events in this category (the first three, the fifth and the eighth events), the EMBI spread changes significantly at the expected direction for almost all of the countries. The negative impact of 11 September 2001 can also be detected in this table. In the consecutive two events following the terrorist activities, although there was a negative policy surprise, the EMBI spread increased significantly for all of the economies in the sample.
Next, Table 5 summarizes the results for the cases when the FED follows a less expansionary policy than the expected.

For the second and the fifth events in this category, the EMBI spread for almost half of the countries change significantly at the expected direction. However, the results are far from being clear to draw a robust conclusion.

As a result, based on the above findings, the perceived risk in the emerging markets seem to change significantly at the expected direction, only when the FED eases its policy rate more than the expected. However, even for that case, the negative effects of 11 September should be taken into account. 
Table 6. Cragg-Donald test results

\begin{tabular}{lll}
\hline $\begin{array}{l}\text { Null hypothesis: } \\
\text { number of factors }\end{array}$ & Wald statistic & $p$-values \\
\hline 0 & 59.58 & 0.00001 \\
1 & 23.72 & 0.055 \\
2 & 6.14 & 0.63 \\
\hline
\end{tabular}

\section{Robustness Check and Concluding Remarks}

It can well be argued that, other than the FED's policy surprise, there may be additional factors, which affect the EMBI spread during the specified event windows. For this purpose, the rank test proposed by Cragg and Donald (1997) is employed. The procedure treats these other factors as unobserved and it tests the null hypothesis of the number of factors that cannot be rejected in explaining the change in the EMBI spread. As Table 6 shows, the null hypothesis that the changes in the EMBI spread can be explained only by a single factor can be rejected. Thus, one can conclude that the findings of the previous section cannot be solely attributed to the policy surprises of the FED.

Finally, it can be claimed that the effects of the FED's policy surprises on the risk component of the emerging markets can be detected by concentrating on another variable. For this purpose, it was investigated whether these surprises alter significantly the nominal exchange rates for these economies during the specified event windows. It could be the case that a policy surprise by the FED changes the risk perception for the emerging markets, which could generate short-term capital flows and alter the nominal exchange rates. However, even after controlling for the fixed exchange rate regimes for the sample period, one could not find a significant link from the FED's policy surprises to the nominal exchange rates. It can also be argued that the stock returns and the sovereign bond ratings convey important information about the policy surprises. However, since the EMBI spread partly reflects the abnormal returns in the stock prices and the changes in the sovereign bond ratings, these variables were not included in the analysis. Also, since the main interest is to evaluate the risk perception that is caused by the policy surprises, the study focused on the EMBI spread, which has been used as the conventional risk measure in many empirical studies.

Consequently, the above findings suggest that the policy surprises of the FED seem to be mostly ineffective in changing the country-specific risk factor of the emerging market economies. The results obtained both from the rank test and the nominal exchange rates further support this notion.

\section{References}

Bernanke, B. S. and Kuttner, K. N. (2004) What explains the stock market's reaction to Federal Reserve policy?, National Bureau of Economic Research Working Papers: 10402 .

Calvo, G. (2002) Explaining sudden stop, growth collapse and BOP crisis, 2002 Mundell-Fleming Lecture, IMF.

Cragg, J. and Donald, S. (1997) Inferring the rank of a matrix, Journal of Econometrics, 76, 223-50.

Fatum, R. and Hutchison, M. (2003) Is sterilized foreign exchange intervention effective after all? An event study approach, Economic Journal, 113, 390-411.

Gurkaynak, R., Sack, B. and Swanson, E. T. (2005) Do actions speak louder than words? The response of asset prices to monetary policy actions and statements, International Journal of Central Banking, 1, 55-93.

Kuttner, K. N. (2001) Monetary policy surprises and interest rates: Evidence from the FED funds futures market, Journal of Monetary Economics, 47, 523-44.

MacKinlay, A. C. (1997) Events studies in economics and finance, Journal of Economic Literature, 15, 13-39. 